\title{
Kontribusi Model Problem Based Learning terhadap Peningkatan Kemampuan Koneksi dan Pemecahan Masalah Matematik
}

\author{
Ratna Rustina', Witri Nur Anisa² \\ 1 Universitas Siliwangi \\ ratnarustina@unsil.ac.id \\ 2Universitas Siliwangi \\ witrinuranisa@unsil.ac.id
}

\begin{abstract}
Abstrak
Tujuan dari penelitian ini adalah untuk mengetahui peningkatan kemampuan koneksi dan pemecahan masalah matematik mahasiswa, mana yang lebih baik antara yang mengikuti pembelajaran melalui model Problem Based Learning dengan yang mengikuti pembelajaran konvensional, peningkatan kemampuan koneksi dan pemecahan masalah matematik mahasiswa, mana yang lebih baik pada kelompok atas dan bawah antara yang mengikuti pembelajaran melalui model Problem Based Learning dengan yang mengikuti pembelajaran konvensional. Populasi dalam penelitian ini adalah seluruh mahasiswa program studi pendidikan matematika Universitas Siliwangi angkatan 2014/2015, sedangkan untuk menentukan sampel dalam penelitian ini menggunakan teknik Purposive Random Sampling terpilih kelas 2014 E sebagai kelas eksperimen dan kelas 2014 D sebagai kelas kontrol. Instrumen yang digunakan dalam penelitian ini adalah soal tes kemampuan koneksi matematik dan soal tes kemampuan pemecahan masalah matematik. Hasil penelitian menunjukan bahwa 1) peningkatan kemampuan koneksi matematik mahasiswa yang mengikuti pembelajaran melalui model Problem Based Learning lebih baik dengan yang mengikuti pembelajaran konvensional, 2) peningkatan kemampuan pemecahan matematik mahasiswa yang mengikuti pembelajaran melalui model Problem Based Learning lebih baik dengan yang mengikuti pembelajaran konvensional, 3) terdapat perbedaan peningkatan kemampuan koneksi dan pemecahan masalah matematik mahasiswa kelompok atas dan bawah yang memperoleh pembelajaran melalui model Problem Based Learning dengan yang mengikuti pembelajaran konvensional.
\end{abstract}

Kata kunci: Problem Based Learning, kemampuan koneksi matematik, kemampuan pemecahan masalah matematik.

\section{PENDAHULUAN}

Matematika sebagai ilmu yang memiliki kemampuan berpikir tingkat tinggi dapat menjadi dasar yang penting untuk dapat mengatasi berbagai tantangan dan tuntutan pada era perkembangan pengetahuan saat ini. Oleh karena itu, kemampuan berpikir tingkat tinggi mahasiswa seperti kemampuan memecahkan masalah, berargumentasi secara logis, bernalar, menjelaskan dan menjustifikasi, memanfaatkan sumber informasi, berkomunikasi, bekerjasama, menyimpulkan dari berbagai situasi, pemahaman konseptual, dan pemahaman prosedural, perlu dikembangkan dalam pembelajaran matematika. Hendriana, Heris dan Utari Sumarmo (2014) menyatakan bahwa pembelajaran matematika sebaiknya memenuhi keempat pilar pendidikan masa datang, yakni (1) learning to know, (2) learning to do, (3) learning to be dan (4) learning to live togheter in peace and harmony. Keempat pilar ini bukan suatu urutan melainkan saling melengkapi satu dengan yang lainnya.

Menyikapi permasalahan yang terjadi bahwa kemampuan koneksi dan pemecahan masalah matematik di tingkat perguruan tinggi belum tertangani. Khususnya pada mata kuliah Program Linier, tidak semua mahasiswa mampu menyelesaikan soal-soal yang tidak rutin. Hal ini mengakibatkan kemampuan koneksi dan pemecahan masalah matematik mahasiswa rendah. Salah satunya hal ini dipengaruhi oleh kemampuan koneksi dan pemecahan masalah matematik mahasiswa pada saat menempuh pembelajaran di tingkat menengah. Rendahnya kemampuan matematika mahasiswa dilaporkan dari hasil beberapa penelitian. Ruspiani (Gordah, 2009) mengungkapkan bahwa, rerata kemampuan koneksi matematis mahasiswa sekolah menengah masih rendah. Misalnya, menurut Ruspiani, nilai rerata untuk koneksi matematis kurang dari 60 pada skor 100 (22,2\%), dan 67,3\% untuk koneksi matematika pada kehidupan sehari-hari.

Kenyataan yang menunjukkan bahwa rendahnya kemampuan koneksi dan pemecahan masalah matematik mahasiswa dipengaruhi oleh beberapa faktor, diantaranya penggunaan model pembelajaran yang tidak tepat sehingga menimbulkan kebosanan mahasiswa, serta mahasiswa kurang terbiasa dalam mengerjakan soal-soal yang tidak rutin dan soal yang memiliki kemampuan koneksi matematik. Faktorfaktor tersebut dapat menyebabkan mahasiswa tidak dapat menyerap materi perkuliahan secara maksimal. 
Menyikapi rendahnya kemampuan koneksi dan pemecahan masalah matematik yang akan mempengaruhi prestasi belajar mahasiswa, maka upaya inovatif untuk menanggulanginya perlu dilakukan oleh dosen. Salah satu solusi yang dapat dilakukan dalam meningkatkan kemampuan koneksi dan pemecahan masalah matematik adalah melalui model Problem Based Learning. Sejalan dengan hal tersebut Gardner (Wena, 2008) menyatakan bahwa pembelajaran berbasis masalah memberikan peluang bagi mahasiswa untuk melibatkan kecerdasan majemuk, dan dapat mengembangkan kemampuan pemecahan masalah matematika mahasiswa.

Melalui model Problem Based Learning mahasiswa dapat mengkonstruksi konsep matematika melalui proses adaptasi dan organisasi. Perkembangan struktur mental mahasiswa bergantung pada pengetahuan yang diperoleh mahasiswa melalui proses asimilasi dan akomodasi sehingga terjadi keseimbangan antara proses asimilasi dan akomodasi. Melalui model Problem Based Learning diharapkan mahasiswa dapat menghubungkan konsep matematika yang digunakan dalam memecahkan masalah matematik yang berkaitan dengan kehidupan nyata. Kemampuan menghubungkan (koneksi) konsep matematika dan kemampuan pemecahan masalah matematik akan terjadi pada struktur kognitif mahasiswa. Berdasarkan kelebihan model Problem Based Learning yang telah diuraikan, peneliti melakukan penelitian dengan judul "Kontribusi Model Problem Based Learning terhadap Peningkatan Kemampuan Koneksi dan Pemecahan Masalah Matematik".

Tujuan yang ingin dicapai dalam penelitian ini adalah untuk mengetahui:

1. Peningkatan kemampuan koneksi matematik mahasiswa yang lebih baik antara yang mendapatkan pembelajaran melalui model Problem Based Learning dengan yang mendapatkan pembelajaran konvensional;

2. Peningkatan kemampuan pemecahan masalah matematik mahasiswa yang lebih baik antara yang mendapatkan pembelajaran melalui model Problem Based Learning dengan yang mendapatkan pembelajaran konvensional;

3. Peningkatan kemampuan koneksi matematik mahasiswa yang lebih baik pada kelompok atas dan bawah antara yang mendapatkan pembelajaran melalui model Problem Based Learning dengan yang mendapatkan pembelajaran konvensional;

4. Peningkatan kemampuan pemecahan masalah matematik mahasiswa yang lebih baik pada kelompok atas dan bawah antara yang mendapatkan pembelajaran Problem Based Learning dengan yang mendapatkan pembelajaran konvensional;

Hipotesis penelitian ini adalah:

1. Kemampuan koneksi matematik mahasiswa yang mendapatkan pembelajaran dengan model Problem Based Learning lebih baik daripada kemampuan koneksi matematik mahasiswa yang mendapatkan pembelajaran konvensional.

2. Kemampuan pemecahan masalah matematik mahasiswa yang mendapatkan pembelajaran dengan model Problem Based Learning lebih baik daripada kemampuan pemecahan masalah matematik mahasiswa yang mendapatkan pembelajaran konvensional.

3. Terdapat perbedaan peningkatan kemampuan koneksi matematik mahasiswa kelompok atas dan bawah antara yang memperoleh pembelajaran dengan model Problem Based Learning dengan mahasiswa yang memperoleh pembelajaran konvensional.

4. Terdapat perbedaan peningkatan kemampuan pemecahan masalah matematik mahasiswa kelompok atas dan bawah antara yang memperoleh pembelajaran berbasis masalah dengan mahasiswa yang memperoleh pembelajaran konvensional.

Kemampuan koneksi matematik menjadi sangat penting karena akan membantu penguasaan pemahaman konsep yang bermakna dan membantu menyelesaikan tugas pemecahan masalah melalui keterkaitan antar konsep matematika dan antara konsep matematika dengan konsep dalam disiplin lain. Hendriana, Heris dan Utari Sumarmo (2014) merangkum kegiatan yang terlibat dalam tugas koneksi matematik yaitu sebagai berikut.

a. Mamahami representasi ekiuvalen suatu konsep, proses, atau prosedur matematik.

b. Mencari hubungan berbagai representasi konsep, proses, atau prosedur matematik.

c. Memahami hubungan antartopik matematika.

d. Menerapkan matematika dalam bidan lain atau dalam kehidupan sehari-hari.

e. Mencari hubungan satu prosedur dengan prosedur lain dalam representasi yang ekiuvalen.

f. Menerapkan hubungan antartopik matematika dan antara topik matematika dengan topik disiplin ilmu lainnya. 
Kegiatan yang terlibat dalam tugas koneksi matematika di atas menunjukkan bahwa pada dasarnya matematika memuat sejumlah konsep yang salin berelasi, sehingga seorang individu mampu mengkonstruksi dan mengkreasi pemahaman konsep yang bermakna. Demikian pula tugas koneksi matematik terlibat dalam tugas analogi dan generalisasi matematik yang melibatkan keserupaan hubungan antarkonsep dan atau proses matematik. NCTM (Yati, Dedeh ,2014) membagi koneksi matematika ke dalam tiga macam, yaitu koneksi antar topik matematika, koneksi dengan disiplin ilmu pengetahuan yang lain, dan koneksi dengan dunia nyata. Topik-topik dalam matematika yang begitu banyak, sebenarnya satu sama lain memiliki koneksi, sehingga koneksi antar topik dapat membantu mahasiswa untuk dapat menghubungkan berbagai topik tersebut.

Menurut Polya (Yati, Dedeh, 2014) "Pemecahan masalah adalah usaha mencari jalan keluar dari kesulitan untuk mencapai suatu tujuan yang tidak begitu saja segera dapat diatasi". Untuk meningkatkan kemampuan mahasiswa memecahkan masalah matematik, maka salah satu cara yang dapat dilakukan adalah dengan jalan membiasakan mahasiswa mengajukan masalah, soal, atau pertanyaan matematika sesuai dengan situasi yang diberikan oleh guru.

Branca (Hendriana, Heris dan Utari Sumarmo, 2014) menyatakan bahwa pemecahan masalah matematika mempunyai dua makna yakni sebagai suatu pendekatan pembelajaran dan sebagai kegiatan atau proses dalam melakukan doing math. Pemecahan masalah matematik sebagai suatu pendekatan pembelajaran melukiskan pembelajaran yang diawali dengan penyajian masalah kontekstual yang kemudian melalui penalaran induktif mahasiswa menemukan kembali konsep yang dipelajari dan kemampuan matematik lainnya.

Polya (Hendriana, Heris dan Utari Sumarmo, 2014) merinci langkah-langkah kegiatan memecahkan masalah sebagai berikut:

a. Kegiatan memahami masalah

Kegiatan ini dapat diidentifikasi melalui pertanyaan-pertanyaan sebagai berikut: data apa yang tersedia dari soal; Apa yang tidak diketahui dan atau apa yang ditanyakan pada soal; Bagaimana kondisi soal yang diberikan; Mungkinkah kondisi dinyatakan dalam bentuk persamaan atau hubungan lainnya; Apakah kondisi yang ditanyakan cukup untuk mencari yang yang ditanyakan? Apakah kondisi itu cukup atau kondisi itu berlebihan atau kondisi itu saling bertentangan?

b. Kegiatan merencanakan atau merancang strategi pemecahan masalah.

Kegiatan ini dapat diidentifikasi melalui pertanyaan-pertanyaan sebagai berikut: Pernahkah ada soal serupa sebelumnya; Pernahkah ada soal serupa atau mirip dalam bentuk lain; teori mana yang dapat digunakan dalam masalah ini; Pernahkah ada pertanyaan yang sama atau serupa; dapatkah pengalaman dan atau cara yang lama digunakan untuk masalah baru; Apakah harus dicari unsur yang lain? Kembalilah pada definisi; andaikan masalah baru belum dapat diselesaikan, coba pikirkan soal serupa dan selesaikan.

c. Kegiatan melaksanakan perhitungan

Kegiatan ini dapat diidentifikasi melalui pertanyaan-pertanyaan sebagai berikut: Melaksanakan rencana strategi pemecahan masalah pada langkah kegiatan merencanakan atau merancang strategi pemecahan masalah dan memeriksa kebenaran tiap langkah. Memeriksa apakah tiap langkah perhitungan sudah benar. Bagaimanakah menunjukkan atau memeriksa bahwa langkah yang dipilih sudah benar.

d. Kegiatan memeriksa kembali kebenaran hasil atau solusi

Kegiatan ini dapat diidentifikasi melalui pertanyaan-pertanyaan sebagai berikut: Bagaimana cara memeriksa kebenaran hasil yang diperoleh?, Dapatkah diajukan sanggahannya?, Dapatkah solusi yang dicari dengan cara yang lain? Dapatkah hasil atau cara itu digunakan untuk masalah yang lain?

Berdasarkan jawaban atas pertanyaan-pertanyaan tersebut, dapat diambil kesimpulan bahwa kemampuan pemecahan masalah adalah usaha atau cara siswa dalam menyelesaikan persoalan dengan menggunakan langkah-langkah sistematis. Pemecahan masalah yang digunakan dalam penelitian ini adalah pemecahan masalah Polya yang mencakup memahami masalah, merencanakan pemecahan, melakukan perhitungan, dan memeriksa kembali hasil.

Problem Based Learning atau yang sering disebut Pembelajaran Berbasis Masalah merupakan model pembelajaran yang dimulai dari pemberian masalah yang berifat ill structured. Artinya, PBM menjadikan Problem Solving sebagai strategi dalam pembelajaran. Menurut Afgani, Jarnawi (2011) terdapat beberapa ciri utama dalam pembelajaran berbasis masalah, yaitu : menyajikan pertanyaan atau masalah; Berfokus pada interdisiplin; penyelidikan otentik; menghasilkan suatu produk; kolaborasi. Alasan penting dari pemberian masalah pada mahasiswa adalah membantu mahasiswa memperoleh wawasan sedemikan hinggn mereka dapat memahami materi pelajaran dan memungkinkan mahasiswa melihatnya dari sudut pandang yang berbeda.

Ditinjau dari aktivitasnya, sintaks untuk pembelajaran berbasis masalah menurut Arends (Afgani, Jarnawi, 2011) disajikan pada tabel berikut. 
Tabel 1. Sintaks Pembelajaran Berbasis Masalah

\begin{tabular}{|l|l|l|}
\hline \multicolumn{2}{|c|}{ Fase } & \multicolumn{1}{c|}{ Prilaku dosen } \\
\hline Fase 1 & $\begin{array}{l}\text { Memberikan orientasi } \\
\text { permasalahan kepada mahasiswa }\end{array}$ & $\begin{array}{l}\text { Dosen membahas tujuan pembelajaran, } \\
\text { mendeskripsikan berbagai kebutuhan logistik } \\
\text { penting, dan memotivasi mahasiswa untuk } \\
\text { terlibat dalam kegiatan mengatasi masalah }\end{array}$ \\
\hline Fase 2 & $\begin{array}{l}\text { Mengorganisasikan mahasiswa } \\
\text { untuk meneliti atau memahami } \\
\text { masalah dan merencanakan } \\
\text { penyelesaiannya. }\end{array}$ & $\begin{array}{l}\text { Dosen membantu mahasiswa untuk } \\
\text { mendefinisikan dan mengorganisasikan tugas- } \\
\text { tugas belajar yang terkait dengan } \\
\text { permasalahannya. }\end{array}$ \\
\hline Fase 3 & $\begin{array}{l}\text { Membantu investigasi mandiri } \\
\text { atau kelompok }\end{array}$ & $\begin{array}{l}\text { Dosen mendorong mahasiswa untuk } \\
\text { mendapatkan informasi yang tepat, } \\
\text { melaksanakan eksperimen, dan mencari solusi. }\end{array}$ \\
\hline Fase 4 & $\begin{array}{l}\text { Mengembangkan dan } \\
\text { mempresentasikan model solusi } \\
\text { dan penyajian. }\end{array}$ & $\begin{array}{l}\text { Dosen membantu mahasiswa dalam } \\
\text { merencanakan dan menyiapkan bahan-bahan } \\
\text { untuk presentasi dan diskusi. }\end{array}$ \\
\hline Fase 5 & $\begin{array}{l}\text { Menganalisis dan mengevaluasi } \\
\text { proses penyelesaian masalah. }\end{array}$ & $\begin{array}{l}\text { Dosen membantu mahasiswa untuk melakukan } \\
\text { refleksi terhadap proses investigasinya dan } \\
\text { proses-proses lainnya yang digunakan dalam } \\
\text { menyelesaikan masalah. }\end{array}$ \\
\hline
\end{tabular}

Situasi masalah yang baik menurut Afgani, Jarnawi (2011) perlu memenuhi lima persyaratan penting, yaitu (a) situsi yang otentik, (b) masalah harus dengan sengaja ditentukan secara tidak tepat (jelek) menumbuhkan teka teki, (c) masalah harus bermakna bagi mahasiswa, (d) masalah harus cukup luas sehingga memungkinkan dosen mencapai tujuan instruksional dan cukup terbatas sehingga dapat dilaksanakan dalam waktu yang tersedia, (e) masalah yang baik harus menguntungkan dari usaha kelompok.

Beberapa penelitian yang sudah dilaksanakan dan relevan dengan penelitian ini antara lain adalah hasil penelitian Ratnaningsih, Nani (2003) yang berjudul "Mengembangkan Kemampuan Berpikir Matematik Mahasiswa SMU Melalui Pembelajaran Berbasis Masalah.” Dalam penelitian dikemukakan bahwa pembelajaran berbasis masalah dapat mengembangkan kemampuan berpikir tingkat tinggi mahasiswa SMU, yakni kemampuan penalaran matematik, koneksi matematik, komunikasi matematik, dan kemampuan pemecahan masalah matematik. Sedangkan, untuk penelitian ini akan dikaji lebih jauh pembelajaran berbasis masalah dalam meningkatkan kemampuan berpikir tingkat tinggi pada aspek kemampuan koneksi dan pemecahan masalah mahasiswa pada tingkat SMP.

Selain itu Yaniawati (2001) melaporkan adanya pandangan mahasiswa SMU yang positif terhadap pembelajaran matematika dan adanya peningkatan kemampuan koneksi matematik yang cukup tinggi setelah dilaksanakan pembelajaran dengan pendekatan open-ended. Sedangkan Noer (2007) dalam penelitiannya yang berjudul "Pembelajaran Open-Ended untuk Meningkatkan Kemampuan Pemecahan Masalah Matematik dan Kemampuan Berpikir Kreatif" menemukan bahwa pembelajaran dengan pembelajaran open-ended dapat meningkatkan kemampuan pemecahan masalah matematik. Akan tetapi masih banyak kelemahan yang ditemui pada mahasiswa pada aspek merumuskan masalah dan menguji kebenaran jawaban dari keempat aspek yang diamati (merumuskan masalah, merencanakan strategi penyelesaian, menerapkan strategi penyelesaian dan menguji kebenaran jawaban). Penelitian Noer tersebut relevan dengan penelitian yang akan dilakukan, yakni terdapat persamaan variabel yang diteliti (peningkatan koneksi dan pemecahan masalah matematik) akan tetapi pembelajaran yang diterapkan menggunakan pembelajaran berbasis masalah serta sampel penelitiannya adalah mahasiswa SMP.

Begitu juga hasil penelitian Nasir (2008) yang berjudul "Meningkatkan Kemampuan Koneksi dan Pemecahan Masalah Matematik Mahasiswa SMA yang Berkemampuan Rendah Melalui Pendekatan Konstektual" menyimpulkan bahwa pembelajaran dengan pendekatan konstektual dapat meningkatkan kemampuan koneksi matematik dan pemecahan masalah matematik mahasiswa yang berkemampuan rendah. Sejalan dengan beberapa hasil penelitian yang sudah dilaksanakan walaupun ditingkat menengah, menjadikan dasar atau acuan bagi peneliti untuk melakukan penelitian di tingkat perguruan tinggi dengan judul "Kontribusi Model Problem Based Learning terhadap Peningkatan Kemampuan Koneksi dan Pemecahan Masalah Matematik.

\section{METODE PENELITIAN}

Penelitian ini merupakan penelitian kuantitatif, karena data yang dikumpulkan dan digunakan adalah data berupa angka-angka hasil eksperimen tes kemampuan koneksi dan pemecahahan masalah matematik.

Penelitian ini menggunakan desain menurut Ruseffendi, E.T.(2005: 50) sebagai berikut. 


\section{$\mathrm{O} \quad \mathrm{X} \quad \mathrm{O}$ \\ $\mathrm{O} \quad \mathrm{O}$}

Keterangan :

$\mathrm{O}=$ Pretes dan Postes kemampuan koneksi dan pemecahan masalah matematik pada kelas eksperimen dan kelas kontrol

$\mathrm{X}=$ Model Problem Based Learning

Penggunaan desain ini bertujuan untuk mengetahui peningkatan kemampuan koneksi dan pemecahan masalah matematik mahasiswa melalui model Problem Based Learning. Dalam penelitian ini, variabel bebasnya adalah model Problem Based Learning dan variabel terikatnya adalah kemampuan koneksi dan pemecahan masalah matematik.

Populasi dalam penelitian ini adalah seluruh mahasiswa program studi pendidikan matematika Universitas Siliwangi angkatan 2014/2015, sedangkan untuk menentukan sampel dalam penelitian ini menggunakan teknik Purposive Random Sampling.Sampel penelitian adalah mahasiswa yang sudah terdaftar dengan kelasnya masing-masing sebanyak dua kelas, sehingga tidak dimungkinkan untuk membuat kelompok baru secara acak. Satu kelompok dijadikan sebagai kelompok eksperimen yaitu kelas 2014 E dan satu kelompok dijadikan kelompok kontrol yaitu kelas 2014 D. Kedua kelompok diberikan Pretes dan Postes. Pada kelompok eksperimen diberikan perlakuan yang berbeda dengan kelompok kontrol. Metode ini dipilih karena selama eksperimen tidak memungkinkan untuk mengubah kelas yang telah ada, pretes dilakukan untuk menyetarakan pengetahuan awal kedua kelompok sedangkan postes digunakan untuk mengukur kemampuan mahasiswa setelah mengikuti pembelajaran dengan model Problem Based Learning.

Pengelompokkan sampel pada kelas eksperimen dan kontrol ke dalam kelompok atas dan bawah dilakukan berdasarkan kemampuan akademik, yaitu hasil belajar semester genap. Kelompok atas adalah mahasiswa yang memperoleh nilai diatas rata-rata kelas dan kelompok bawah merupakan mahasiswa yang memperoleh nilai di bawah rata-rata kelas. Kelompok atas dan bawah di sajikan dalam lampiran.

Penelitian ini menggunakan instrumen berupa soal tes kemampuan koneksi dan pemecahan masalah matematik. Jenis tes pada penelitian ini adalah pretes dan postes. Pretes dilaksanakan sebelum pembelajaran dilakukan untuk mengetahui kemampuan kemampuan koneksi dan pemecahan masalah matematik. Pada materi yang dipelajari pada kelompok eksperimen dan kelompok kontrol, sedangkan postes diberikan setelah selesai pelaksanaan kegiatan belajar mengajar untuk mengetahui peningkatan kemampuan koneksi dan pemecahan masalah matematik mahasiswa, bentuk soal yang digunakan adalah uraian.

Tes kemampuan pemecahan masalah matematik pada penelitian ini digunakan untuk mengukur kemampuan pemecahan masalah matematik mahasiswa. Penilaian untuk jawaban terhadap soal pemecahan masalah matematik mahasiswa disesuaikan dengan keadaan soal dan hal-hal yang ditanyakan.

Sebelum digunakan, instrumen tersebut diujicobakan terlebih dahulu, supaya dapat terukur validitas dan reliabilitasnya.

1. Soal kemampuan Koneksi Matematik

a. Validitas Instrumen

Analisis dilakukan dengan program SPSS singkatan dari Statistical Package for the Social Sciences (Uyanto, Stanislaus, 2009). Perhitungan validitas soal dilakukan dengan kriteria jika diperoleh nilai signifikansinya kurang dari taraf signifikansi $(\alpha)$ maka soal tersebut dinyatakan valid, sebaliknya jika nilai signifikansi lebih dari taraf signifikansi $(\alpha)$ maka soal dinyatakan tidak valid. Taraf signifikansi yang digunakan dalam penelitian ini adalah 0,05 . Setelah dilakukan perhitungan didapat bahwa semua soal yang diujicobakan valid berada pada kategori sedang dan tinggi sehingga semua soal yang diujicobakan dapat dipakai.

b. Reliabilitas Instrumen

Koefisien reliabilitas yang diperoleh dari perhitungan dengan menggunakan SPSS, diinterpretasikan ke dalam klasifikasi koefisien reliabilitas menurut Guilford (Rustina, Ratna : 2014). Penghitungan dilakukan dengan menggunakan SPSS 18 dan hasil penghitungan (dapat di lihat pada kolom Cronbach's Alpha) menunjukkan bahwa reliabilitas terhadap 3 butir soal kemampuan pemecahan masalah matematik diperoleh koefisien reliabilitas sebesar 0,67. Dengan demikian seperangkat tes kemampuan pemecahan masalah pada penelitian ini memiliki reliabilitas sedang.

2. Soal kemampuan Pemecahan Masalah Matematik

a. Validitas Instrumen

Perhitungan validitas soal dilakukan dengan kriteria jika diperoleh nilai signifikansinya kurang dari taraf signifikansi $(\alpha)$ maka soal tersebut dinyatakan valid, sebaliknya jika nilai signifikansi lebih dari taraf signifikansi $(\alpha)$ maka soal dinyatakan tidak valid. Taraf signifikansi yang digunakan dalam penelitian ini adalah 0,05 . Setelah dilakukan perhitungan semua soal yang diujicobakan valid dan berada pada kategori tinggi sehingga semua soal dapat digunakan sebagai instrument. 


\section{b. Reliabilitas Instrumen}

Hasil penghitungan (dapat di lihat pada kolom Cronbach's Alpha) menunjukkan bahwa reliabilitas terhadap dua butir soal kemampuan pemecahan masalah matematik diperoleh koefisien reliabilitas sebesar 0,789. Dengan demikian seperangkat tes kemampuan pemecahan masalah pada penelitian ini memiliki reliabilitas tinggi

Data yang diperoleh dari penelitian ini diolah untuk mendapatkan informasi yang diinginkan. Data tersebut berasal dari Pretes dan Postes yang diberikan pada kedua kelompok. Data yang telah diperoleh kemudian diolah sebagai berikut.

1. Pengolahan Data Hasil Pretes dan Postes

Data hasil tes tertulis, ada beberapa perhitungan yang dilakukan, antara lain sebagai berikut.

a. Analisis Deskriptif, bertujuan untuk mengetahui gambaran mengenai data yang diperoleh. Adapun data deskriptif yang dihitung adalah skor terendah, skor tertinggi, rata-rata dan standar deviasi.

b. Menghitung Gain Score

Indeks gain ini dihitung dengan rumus indeks gain dari Meltzer (Anisa, Witri Nur, 2014), yaitu sebagai berikut.

$$
g=\frac{S_{\text {Post }}-S_{\text {Pre }}}{S_{\text {Maks }}-S_{\text {Pre }}}
$$

Keterangan:

$S_{\text {Post }}=$ Skor postes

$S_{\text {pre }}=$ Skor pretes

$S_{\text {maks }}=$ Skor maksimal

\section{HASIL DAN PEMBAHASAN}

Pembelajaran dengan model Problem Based Learning dalam penelitian ini dilaksanakan sendiri oleh peneliti pada kelas ekaperimen. Dalam pembelajaran dengan model Problem Based Learning pada mata kuliah Program Linier, dosen mempersiapkan bahan ajar, lembar kerja mahasiswa, serta tugas individu untuk membantu mahasiswa memahami materi pembelajaran yang dibahas. Dalam bahan ajar disajikan beberapa hal yang dibutuhkan sebagai penunjang pembelajaran dengan model Problem Based Learning.

Pada pertemuan pertama, mahasiswa masih terlihat bingung dan kaku dalam pembelajaran dengan model PBL. Namun, pada pertemuan selanjutnya mahasiswa dapat mengikuti pembelajaran dengan lancar dan terlihat kemandirian dan aktif dalam diskusi kelompok di kelas. Mahasiswa saling bertukar informasi dan pengetahuan selama diskusi berlangsung. Sejalan dengan pendapat Vygotsky(Yati, Dedeh, 2014) menyatakan bahwa pembentukan dan pengembangan ilmu pengetahuan terjadi melalui interaksi sosial.

Penelitian ini dilakukan selama tujuh kali pertemuan, dimana sebelum dilaksanakan pembelajaran dilakukan tes awal atau pretes. Hasil pretes menunjukan bahwa kemampuan koneksi dan kemampuan pemecahan masalah matematik mahasiswa kelas eksperimen dan kelas kontrol memiliki kemampuan awal yang sama. Selanjutnya, mahasiswa diberikan postes untuk mengetahui kemampuan kemampuan koneksi dan kemampuan pemecahan masalah matematik mahasiswa pada akhir pembelajaran.

Berdasarkan analisis pengujian terhadap hipotesis statistik dengan uji-t pada taraf signifikasi 0,05 ternyata peningkatan kemampuan koneksi dan kemampuan pemecahan masalah matematik mahasiswa yang mendapatkan pembelajaran dengan model Problem Based Learning lebih baik daripada kemampuan koneksi dan kemampuan pemecahan masalah matematik mahasiswa yang mendapatkan pembelajaran konvensional. Pembelajaran dengan model Problem Based Learning lebih mengaktifkan mahasiswa dalam proses berpikir dibandingkan dengan pembelajaran konvensional. Proses berpikir yang dimaksud adalah melakukan investigasi dan eksplorasi, melakukan analisis, mengumpulkan informasi yang berkaitan dengan situasi atau masalah, jawaban-jawaban yang mungkin, mengevaluasi kemungkinan-kemungkinan yang menjadi solusi terbaik. Hasil penelitian ini sejalan dengan pendapat Delisle (Ratnaningsih, Nani, 2003) yang menyatakan bahwa model pembelajaran aktif seperti pembelajaran dengan model Problem Based Learning dapat memberikan motivasi dan meningkatkan pemahaman serta pencapaian peserta didik.

Hasil analisis statistik terhadap kemampuan koneksi dan kemampuan pemecahan masalah matematik mahasiswa menunjukan bahwa pembelajaran dengan model Problem Based Learning dapat meningkatkan kemampuan koneksi dan kemampuan pemecahan masalah matematik mahasiswa dibandingkan dengan pembelajaran konvensional. Hal ini disebabkan pembelajaran dengan model Problem Based Learning mahasiwa berperan aktif dalam proses berpikir dibandingkan pembelajaran konvensional. Dalam model Problem Based Learning mahasiswa berperan aktif menyelesaikan persoalan matematik dengan berlatih untuk memecahkan masalah, mengkontruksi pemahamannya sendiri, menyajikan temuan dengan mengungkapkan proses yang dilakukannya. Hal ini sejalan dengan pendapat Ibrahim dan Nur (2000) yang 
berpendapat bahwa pembelajaran model Problem Based Learning dapat membantu peserta didik/mahasiswa mengembangkan kemampuan berpikir dan pemecahan masalah.

Kelas eksperimen dan kontrol dikelompokkan menjadi dua kelompok, yaitu dari kemampuan awal dimana adanya kelompok atas dan bawah. Hasil analisis statistik, menunjukan bahwa peningkatan kemampuan koneksi dan kemampuan pemecahan masalah matematik mahasiswa dimana pembelajaran dengan model Problem Based Learning lebih baik dibandingan dengan pembelajaran konvensional. Pada pembelajaran konvensional terlihat adanya peningkatan kemampuan koneksi dan kemampuan pemecahan masalah, namun peningkatan yang terjadi kurang optimal dibandingkan dengan pembelajaran model Problem Based Learning. Perbedaan peningkatan ini terletak pada optimalisasi keterlibatan mahasiswa dalam pembelajaran sehingga proses berpikir mahasiswa tidak dilatih secara maksimal. Sesui dengan pendapat Resnick (Ibrahim dan Nur, 2000) mengemukakan bahwa pembelajaran dengan model Problem Based Learning membantu peserta didik/mahasiswa untuk berkinerja dalam situasi kehidupan nyata.

\section{KESIMPULAN}

Berdasarkan hasil penelitian dan analisis yang diperoleh mengenai kemampuan koneksi dan kemampuan pemecahan masalah matematik mahasiswa dengan pembelajaran model Problem Based Learning diperoleh simpulan sebagai berikut.

1. Peningkatan kemampuan koneksi matematik mahasiswa yang mendapatkan pembelajaran model Problem Based Learning lebih baik dibandingkan dengan mahasiswa yang mendapatkan pembelajaran konvensional;

2. Peningkatan kemampuan pemecahan masalah matematik mahasiswa yang mendapatkan dengan pembelajaran model Problem Based Learning lebih baik dibandingkan dengan mahasiswa yang mendapatkan pembelajaran konvensional;

3. Peningkatan kemampuan koneksi matematik mahasiswa pada kelompok atas dan bawah yang mendapatkan pembelajaran model Problem Based Learning lebih baik dibandingkan dengan mahasiswa yang mengikuti pembelajaran konvensional;

4. Peningkatan kemampuan pemecahan masalah matematik mahasiswa pada kelompok atas d ah yang mendapatkan pembelajaran model Problem Based Learning lebih baik dibandingkan den hasiswa yang mengikuti pembelajaran konvensional.

\section{DAFTAR PUSTAKA}

Afgani, J. (2011). Analisis Kurikulum Matematika. Jakarta: Universitas Terbuka.

Anisa, Witri Nur. (2014). Peningkatan Kemampuan Pemecahan Masalah dan Komunikasi Matematik Melalui Pembelajaran Pendidikan Matematika Realistik untuk Siswa SMP Negeri di Kabupaten Garut. Tesis Pascasarjana. Universitas Terbuka

Hendriana, Heris dan Utari, S. (2014). Penilaian Pemmbelajaran Matematika.. Bandung. Refika Aditama.

Ibrahim, M dan Nur, M. (2000). Pembelajaran Berbasis Masalah. Surabaya. UNESA University Press.

Nasir, S. (2008). Meningkatkan Kemampuan Koneksi dan Pemecahan Masalah Matematik Mahasiswa SMA yang Berkemampuan Rendah Melalui Pendekatan Konstektual. Tugas akhir program megister, UPI Bandung. Bandung.

Noer, S. H.(2007). Pembelajaran Open-Ended untuk Meningkatkan Kemampuan Pemecahan Masalah Matematik dan Kemampuan Berfikir Kreatif.Tugas akhir program megister, UPI Bandung. Bandung.

Ratnangingsih, N .(2003). Mengembangkan Kemampuan berpikir Matematik Mahasiswa SMU Melalui Pembelajaran Berbasis Masalah. Tesis pada PPS UPI Bandung. Bandung.

Russefendi, E.T. (2005). Dasar-dasar Penelitian Pendidikan dan Bidang Non-Eksakta Lainnya. Bandung : Tarsito.

Rustina, Ratna. (2014).Pengaruh Penggunaan Pembelajaran Kontekstual Dengan Teknik SQ4R Terhadap Peningkatan Kemampuan Pemahaman dan Pascasarjana. Universitas terbuka.

Yati, Dedeh (2014). Peningkatan Kemampuan Koneksi dan Pemecahan Masalah Matematik Mahasiswa SMP Negeri 14 Tasikmalaya Melalui Pembelajaran Berbasis Masalah. Tesis Pascasarjana. Universitas Terbuka

Yuliawati, R.P. (2001). Pembelajaran dengan Pendekatan Open-ended dalam Upaya Meningkatkan kemampuan Koneksi Matematik Mahasiswa. Tesis pada PPS UPI Bandung. Bandung. 